\title{
Study on Color Matching of Building Facades in Harbin (Cold Regions) Based on NCS Color System
}

\author{
Yu Shao ${ }^{1}$,Jie Liu ${ }^{1}$ and Jirui Wang ${ }^{2, a}$, Wenjie Song ${ }^{2, b}$ \\ ${ }^{1,2}$ School of Architecture, HIT, Harbin (150006), China \\ a1357347337@qq.com, b 457971872@qq.com
}

Keywords: color matching; building facade; cold region

Abstract. With the combination of the visual perception experience and the qualification of NCS color system, a study on color matching of facade of residential buildings in Harbin is made. Analyzing the frequency of occurrence of blackness, chromaticness and hue collected on the residential facade, there appears several results of the study. The key-color of buildings mainly appears within the YR hue, while the co-color of buildings is the color with Y or $\mathrm{N}$ hue. And further contrast on the color of facade among different areas in Harbin shows that the blackness, chromaticness and hue of color matching in the old district are more unified than the new district which has an increased value of blackness and chromaticness.

\section{Introduction}

Research Background. In China, architectural study on color is still a new field, on the contrary, it is already a scientific area with great breadth and depth. For instance, Jean-Philippe Lenclos's group started on the research of residential color and finished the collection of data on color covering 15 areas in France. And then the research expended to 13 European countries. He firstly proposed the concept Color Geography, which contains the procedures in architectural color research, including site selection, investigation, evidence collection, induction, compilation. With the help of widely public opinion, he is looking forward to find the breaking point of urban level research on color [1, 2].

\section{Research Tools.}

NCS Color System. NCS is the most prestigious international color system in terms of color determination standards, as well as common color standards. It is based on human visual perception, consisting of 2 colorless colors (white (W) and black (S)) and 4 colored colors (yellow $(\mathrm{Y})$, red $(\mathrm{R})$, blue $(\mathrm{B})$ and green $(\mathrm{G})$ ), which forms the 6 key-colors that are ideal with no similarity between each other. All colors seen can be generated from them. And NCS color number system describes the relationship between the sample and the 6 key-colors.

NCS color regulations can be summarized as follows:

a) Samples with the same value of blackness are on the $\mathrm{W}-\mathrm{C}$ axis;

b) Samples with the same value of whiteness are on the S-C axis;

c) Samples with the same value of chromaticness are on the W-S axis;

d) Samples with the same value of brightness are in a straight line, but the locations are different due to different hue.

In the actual urban space, due to the light-receiving surface, distance and other factors, visual perception in the aspect of blackness, whiteness and chromaticness is quite different while people watch different facades painted in same color. NCS describes the color from the most intuitive visual perception, which meets with the actual visual experience [3].

Mathematical Model of Urban Color Planning and Design. We can abstract the color matching of urban architecture into a mathematical model that includes including key-color, co-color and highlight-color to form a basis for urban color matching. As key-color covers 
relatively a large area on buildings, it plays a decisive role. So set key-color as a dependent variable, the latter choice should be based on the set of key-color [4].

\section{Sample Collection}

Harbin was effected by several different foreign cultures in history. With the development and change of urban planning construction, Harbin's architectural texture, is now becoming a combination of modern city texture and traditional color texture. In addition, locating in cold region makes Harbin a typical city which attaches the historical facade color system to the cold atmosphere.

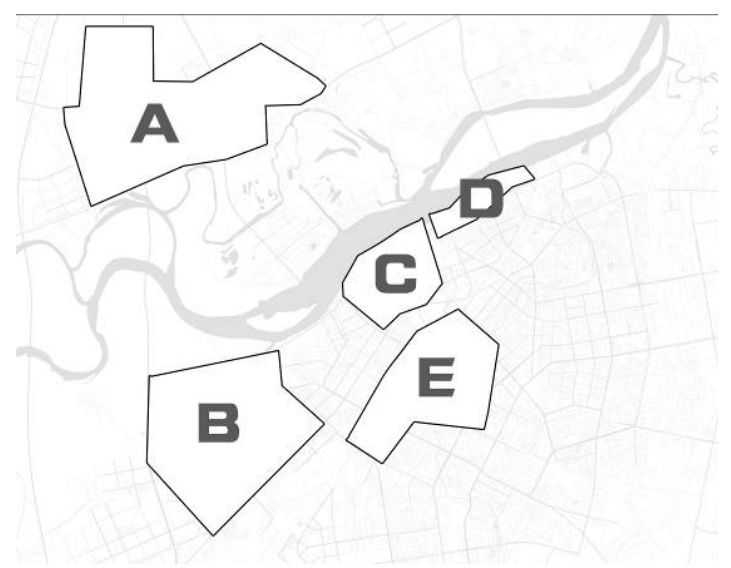

Fig. 1 selected area and its order

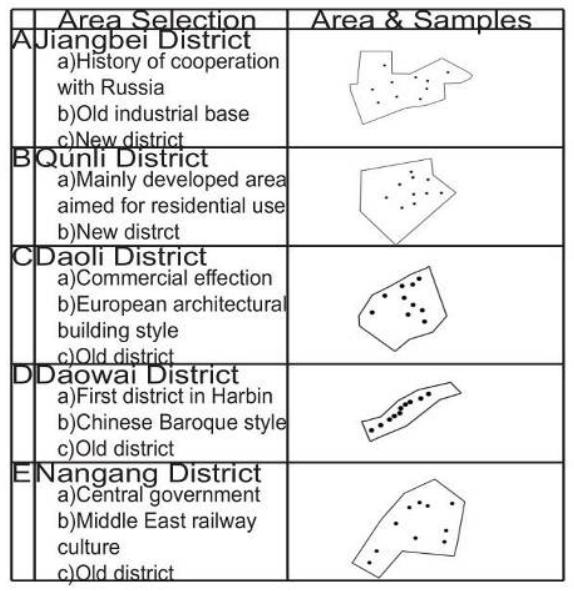

Fig.2 detail information of selected area

In order to analyze the color matching of residential building in Harbin and compare the differences in color matching among different regions of Harbin, we choose Jiangbei District, Qunli District, Daoli District, Daowai District and Nangang District. Then number them with A, B, C, D and $\mathrm{E}$ in order (refer with: Fig.1, Fig.2). Finally select 10 samples on color matching of building each from A, B, C, D and E area, which form a total of 50 samples.

\section{Color Matching and Regional Differences}

Color matching on building facade is regarded as an important factor that influences urban texture. Therefore, we firstly list and sort out all the 50 samples, analyze the statistics and calculate the occurrence frequency of the color involved in color matching on building facade. And then observe the data to find the differences regionally.

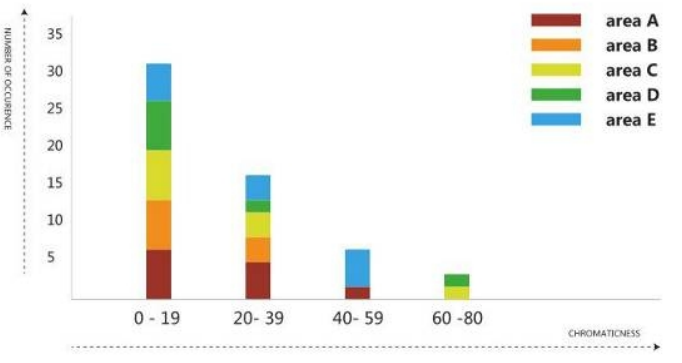

Fig.3 frequency of chromaticness of key-color

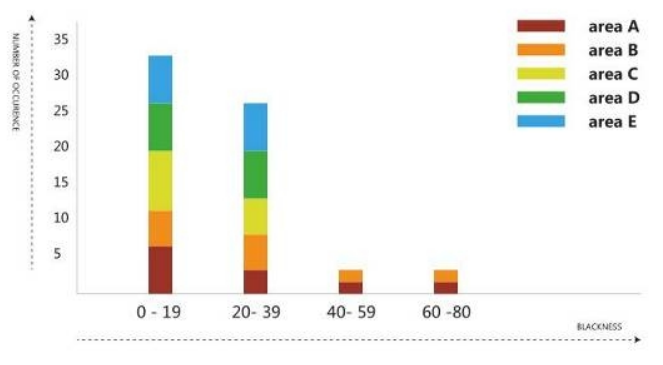

Fig.4 frequency of blackness of key-color 


\section{Frequency of Blackness, Chromaticness and}

Hue on Key-color. Key-color, covering more than $70 \%$ of a building facade, determines temperament of the building. It plays a key role in whether a building adapts to the environment as well as the surrounding buildings.

The frequency of chromaticness values (refer with: Fig.3) that are in the range of 0-19 takes $55 \%$, while the frequency in the range of 20-39 is $32 \%$. Things go different when it comes to the

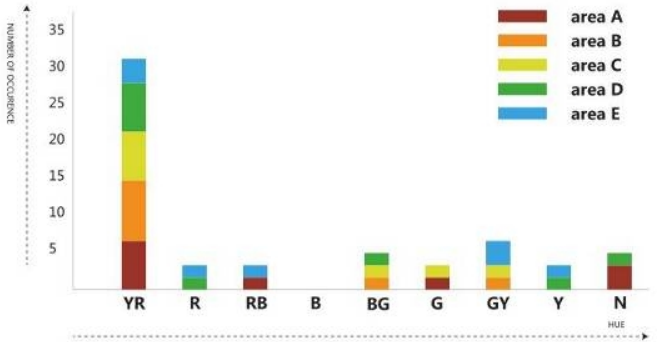

Fig.5 frequency of hue of key-color range of 40-59 and 60-80, obviously, the proportion of frequency in both two ranges is very small. Another breakthrough is that the frequency of blackness (refer with: Fig.4) in each range is similar to the result of chromaticness, which means the proportion of frequency in the range of 0-39 is more than $90 \%$. The key-color of buildings mainly appears within the YR hue (refer with: Fig.5). The consequence that the key-color of building facade in Harbin is mainly Brownish yellow and orange yellow with low values of blackness and chromaticness is made.

Regional Differences in Color Matching. Compared with the relatively earlier constructed districts (Nangang District, Daoli District and Daowai District), Jiangbei District and Qunli District are newly built urban residential area in Harbin. It is distinct that there are differences on color matching of residential building facade between old and new region of city.

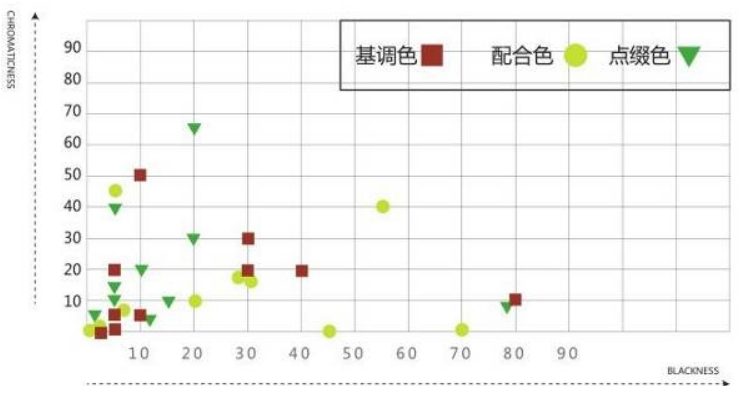

Fig.6 distribution of key-color, co-color and highlight-color on blackness-chromaticness axis. (Area A: Jiangbei District)

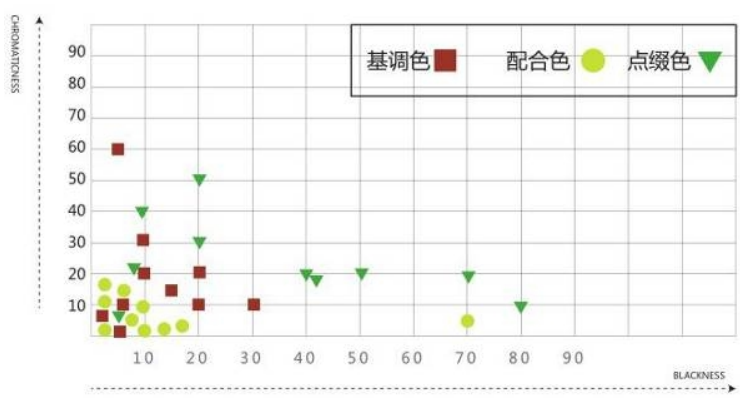

Fig. 8 distribution of key-color, co-color and highlight-color on blackness-chromaticness axis. (Area C: Daoli District)

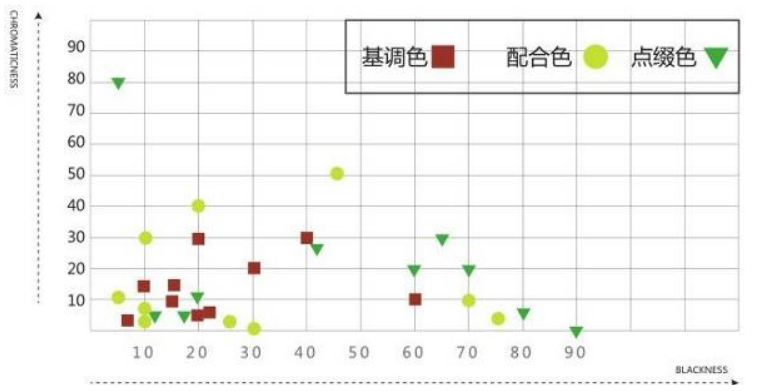

Fig. 7 distribution of key-color, co-color and highlight-color on blackness-chromaticness axis. (Area B: Qunli District)

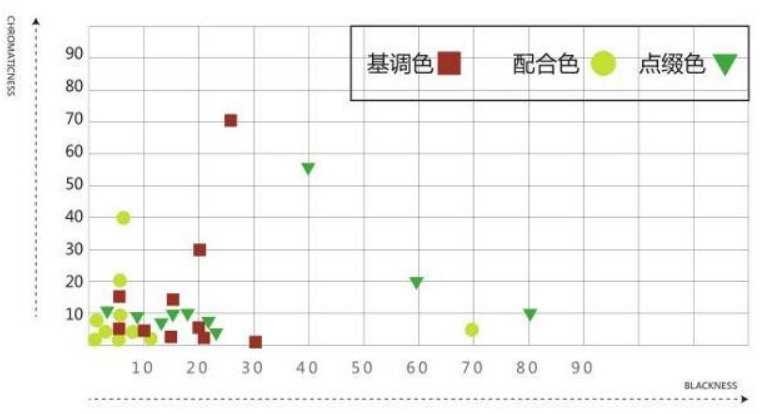

Fig.9 distribution of key-color, co-color and highlight-color on blackness-chromaticness axis. (Area D: Daowai District) 


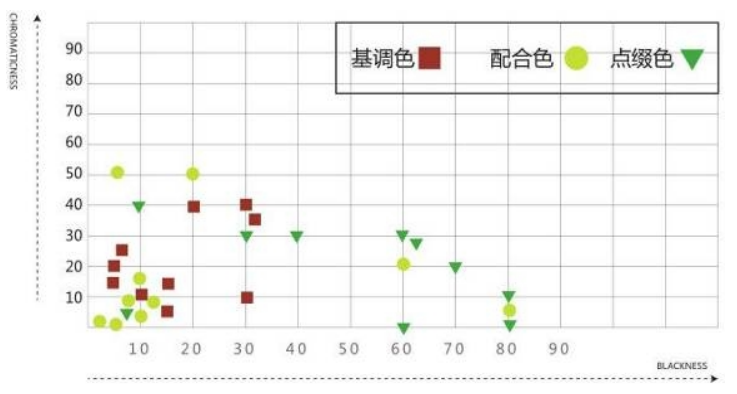

Fig.10 distribution of key-color, co-color and highlight-color on blackness-chromaticness axis.

(Area E: Nangang District)

From the figures above (refer with: Fig.8, Fig.9, Fig.10), it can be seen that except highlight-color, the distribution of key-color and co-color in blackness-chromaticness axis is concentrated in low-value area, which shows that facade color in the old region (Nangang District, Daoli District and Daowai District) is more uniform. On the contrary, the new region's blackness-chromaticness distribution (refer with: Fig.6, Fig.7) is scattered. Though it is still generally based on low value of blackness and chromaticness, some of the color raise the value a little bit to enriched the hierarchical relationship between urban buildings without break the traditional hue of color in the city.

\section{Conclusion}

To sum up, two conclusions are made. On the one hand, from the perspective of Harbin, the whole city, the key-color of residential buildings mainly appears within the YR hue from Y10R to Y90R, accompanied by blackness and chromaticness concentrating within the scope of 0-30; And the co-color of buildings is the color with $\mathrm{Y}, \mathrm{N}$ hue or from Y10R to Y30R, still, low value of blackness and chromaticness. On the other hand, the blackness, chromaticness and hue of color matching in the old districts are more unified than the new districts which have an increased value of blackness and chromaticness.

\section{References}

[1] ZHU Jingjing: Study on Urban Color of Chang'an District in Xi'an Based on Regional Characteristics, Planning and Design Master's Degree in Xi'an University of Architecture and Technology (2010).

[2] XU Liang, WANG Guohua, GAO Guangli: Color Panning and Application of Urban at Cold Region, Architecture and Art Education.

[3] Wu Xinhua: Discussion on the color standard in urban planning and construction, Huazhong University of Science and Technology Architectural Design and Its Theoretical Master's Degree Thesis (2004).

[4] Li Yuan: Research on Application of color data basic, Tianjin University Architectural Technology Science Master's Degree Text (2007). 